\title{
PENGEMBANGAN MODUL BERBANTUAN TEKNOLOGI AUGMENTED REALITY DENGAN PUZZLE PADA MATERI BANGUN RUANG
}

\author{
Sila Amelia, Agus Wedi, Arafah Husna \\ Teknologi Pendidikan, Fakultas Ilmu Pendidikan, Universitas Negeri Malang. \\ Jl. Semarang No.5, Malang, 65145, Indonesia. \\ Silaam1909@gmail.com
}

\section{Article History}

Received: 22 Januari 2021, Accepted: 11 April 2021, Published: 20 Februari 2022

\begin{abstract}
Abstrak
Pembelajaran mengenai bangun ruang sering diterapkan pada media buku seperti teks dan gambar dua dimensi saja. Dalam hal ini mengakibatkan pembelajaran menjadi kurang optimal sehingga diperlukan sebuah media pembelajaran yang dapat membantu siswa SD dalam memahami karakteristik dasar bentuk bangun ruang dengan menunjukkan bentuk objek secara tiga dimensi. Tujuan pengembangan ini yakni untuk menghasilkan produk buku modul yang telah dilengkapi teknologi Augmented Reality dengan puzzle pada mata pelajaran bangun ruang untuk kelas IV SD. Metode yang digunakan dalam penelitian ini yaitu jenis penelitian pengembangan yang dikenal dengan istilah Research \& Development (R\&D). Model pengembangan yang digunakan adalah model Lee \& Owens yang telah disesuaikan dengan kebutuhan penelitian. Adapun tanggapan dari ahli media dan ahli materi mendapatkan respon positif setelah dilaksanakan uji coba. Sedangkan uji coba pemanfaatan produk dilakukan terhadap siswa SD Kelas IV. Dan hasil yang didapatkan secara keseluruhan produk media modul Augmented Reality dengan puzzle pada materi bangun ruang layak digunakan dalam pembelajaran.
\end{abstract}

Kata kunci: Modul; Augmented Reality; Puzzle; Matematika

\begin{abstract}
Learning about solid figure is often applied to book media such as text and two-dimensional images only. In this case, in learning process a learning medium is needed that can help elementary students in understanding the basic characteristics of the shape of a room by displaying the shape of objects in three dimensions. The purpose of this development is to produce a module book product that has been equipped with Augmented Reality technology with puzzles on the subjects of building space for grade IV SD. The method used in this study is a type of development research known as Research \&D. The development model used is the Lee \&Owens model that has been adapted to the needs of research. The response from media experts and material experts received a positive response after the trial. Meanwhile, product utilization trials were conducted on grade IV elementary school students. And the results obtained overall Augmented Reality module media products with puzzles on space building materials worth using in learning.
\end{abstract}

Keyword: Module; Augmented Reality; Puzzle; Mathematics 


\section{PENDAHULUAN}

Pendidikan inovatif merupakan hal yang wajib dilakukan di dunia pendidikan. Banyak usaha dilakukan bertujuan pembaruan dalam pendidikan. Permendikbud nomor 65 menyatakan bahwa perubahan standar proses pendidikan dasar dan menengah serta sistem dalam pembelajaran dan penilaian belajar sangat perlu untuk dilakukan, hal ini merupakan wujud implikasi dari adanya perubahan dalam dalam standar tersebut (Permendikbud, 2016). kebijakan ini berwujud pembaruan kurikulum 2013 dengan bertujuan menciptakan masyarakat indonesia mampu berfikir produktif, afektif, inovatif, dan kreatif melalui pengembangan keterampilan pengetahuan, sikap dan keterampilan secara integratif.

Salah satu usaha yang dilakukan dalam mencapai tujuan proses pembelajaran secara efektif yakni dihadirkannya sumber belajar untuk siswa, seperti buku modul untuk siswa atau buku penunjang pembelajaran. Selain itu ketersediaan media pembelajaran yang bervariasi akan sangat bermanfaat bagi anak untuk memenuhi karakteristik belajar siswa yang beragam. Penyiapan materi adalah sebuah esensi penting dalam pembelajaran, materi konten harus relevan dengan konsep yang dipelajari (Orlich et al., 2012). Maka dari itu salah satu sumber belajar yang dapat dimanfaatkan yakni modul.

Modul adalah bahan ajar berisi konten relevan, singkat dan spesifik dengan tujuan tercapainya tujuan pembelajaran. Sebagai salah satu jenis bahan ajar memiliki karakteristik berprinsip belajar mandiri (Meyer, 1978). Belajar mandiri merupakan cara belajar yang aktif dan partisipasi untuk pengembangan pengetahuan dalam diri tiap individu dengan tidak ada keterikatan kehadiran guru, pertemuan disekolah dan rekan sekolah.

Dalam mempelajari konsep matematika, anak melalui 3 tahapan yakni iconic, symbolic dan enactive. iconic yakni tahapan belajar dengan memanfaatkan gambar, symbolic yakni memahami dengan memanipulasi symbol, dan tahap enactive yakni tahapan belajar dengan cara memanipulasi objek atau benda konkrit,. Sedangkan menurut (Piaget, 1976) taraf perkembangan berfikir usia SD adalah masih konkret operasional, bahwa dalam mempelajari konsep, anak diberikan kegiatan yang memiliki hubungan benda nyata yang dapat diterima oleh akal mereka. Objek berbentuk fisik dapat membantu siswa untuk menghubungkan antara pemahaman secara penglihatan dan indra perasa mereka, termasuk juga berhubungan dengan spasial mereka dan membantu siswa memfokuskan perhatian (Billinghurst, 2002).Sehingga menjadi hal penting untuk memanipulasi objek dalam matematika. Belajar matematika adalah proses merekonstruksi konsep dan prinsip, bukan terhenti dalam hal sekedar belajar terkesan statis dan pasif, namun proses pembelajaran itu harus aktif dan dinamis (Rusnandi et al., 2016).

Dari hasil observasi dan wawancara di SDN Punten 01 ditemukan bahwa kegiatan pembelajaran yang dilakukan di SDN Punten 01 Kota Batu tematik tema 4 materi bangun ruang. Salah satu kompetensi dasar yang akan dicapai adalah siswa mampu memahami gambar dan bentuk tiga dimensi serta siswa mampu menggambar dan membentuk tiga dimensi. Namun ditemukan beberapa fakta bahwasannya dalam kegiatan pembelajaran hanya berpedoman pada buku cetak dan metode ceramah dirasa masih kurang optimal dalam memenuhi perbedaan gaya belajar siswa yang beragam. Selain itu materi dalam buku cetak dirasa kurang optimal karena dalam memahami materi bangun ruang diperlukan visualisasi konkrit yang tidak cukup hanya teks dan gambar saja. Media berupa buku sebagai media dan suplemen berteknologi AR dapat membantu pengajar menyampaikan materi dengan visualisasi 3D dalam buku cetak, sehingga menarik dan mempermudah pemahaman materi (Abdillah et al., 2020). Guna mengatasi masalah tersebut dengan keunggulan menggabungkan dunia nyata dengan dunia virtual, teknologi AR 
sangat berpotensi besar sebagai penunjang kegiatan belajar dalam pendidikan dan meningkatkan kualitas pembelajaran selama proses itu berlangsung (Nincarean et al., 2013).

Berdasarkan pemaparan permasalahan diatas, buku penunjang tambahan seperti kombinasi antara modul dengan teknologi Augmented Reality pada platform Android dirasa cukup untuk memenuhi kebutuhan konteks penyajian materi. Sehingga dapat memberikan siswa kemudahan dan fleksibilitas waktu mengeksplorasi objek abstrak yang diproyeksikan dalam bentuk 3D. Tidak hanya itu, pembeda produk pengembangan modul Augmented Reality ini dengan penelitian sebelumnya yakni penambahan fitur mekanisme Puzzle pada marker sehingga ketika 2 marker disatukan akan terjadi reaksi animasi jaring-jaring tergantung pada objek jenis bangun ruang yang sedang diproyeksikan, sehingga peserta didik belajar dengan lebih menyenangkan, interaktif dan menarik.

\section{METODE}

Metode penelitian yang digunakan dalam mengembangkan modul Augmented Reality menggunakan prosedur model pengembangan oleh Lee \& Owens. Untuk itu metode penelitian ini Penggunaan metode ini dirasa tepat karena dilengkapi desain instruksional dalam pengembangan angket dan mencantumkan respon pengalaman dari pengguna sehingga dapat dihasilkan produk media yang layak digunakan. Berikut merupakan alur tahapan pengembangan oleh Lee \& Owens:

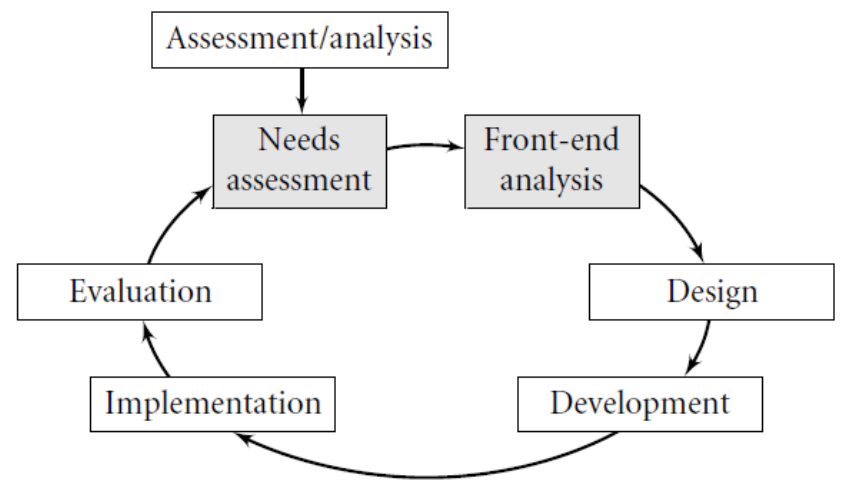

Gambar 1. Model pengembangan Lee \& Owens (2004)

Model pengembangan oleh Lee \& Owens terdiri dari 5 tahap disebut dengan penilaian/analisis (assessment/analysis) terdiri 2 bagian yaitu analisis kebutuhan (need analysis) dan analisis awal akhir (front end analysis), berikutnya desain (design), pengembangan (development), implementasi (implementation), dan terakhir evaluasi (evaluation). Namun pengembangan ini hanya dilaksakan hingga pada tahapan pengembangan(development)

Pada tahapan analisis sebelum dilakukan pengembangan media pembelajaran, tahap pertama yang dilakukan adalah melakukan observasi. hal ini penting dilakukan untuk memahami kendala dan kebutuhan yang ada dilapangan agar pengembangan media pembelajaran yang telah dilakukan sesuai dengan kebutuhan. Menurut (Lee \& Owens, 2004) pada tahap assessmen terbagi menjadi 2 tahap yakni, analisis kebutuhan dan analisis awal-akhir.

Tahapan analisis awal akhir (front-end develompent) dilanjutkan pada kegiatan analisis secara lebih lanjut. Pada bagian ini dijabarkan jenis-jenis analisis yang diantaranya (1) audience analysis, (2) technology analisis, (3) task analysis, (4) critical incident analysis, (5) situational analysis, (6) objective analysis, (7) issue analysis, (8) media analysis, (9) extant-data analysis, dan (10) costbenefit analysis. 
Tahapan desain. (Lee \& Owens, 2004) Terdapat beberapa poin yang perlu dilakukan dalam tahapan desain yakni jadwal kegiatan, tim dalam proyek, dan spesifikasi media. Pada tahap ini pengembang mulai menentukan perencanaan produk baik spesifikasi media, informasi konten dan control konfigurasi.

Dalam tahapan development, materi bangun ruang mulai dikumpulkan dan disusun kedalam aplikasi dan modul. Terdapat 2 macam marker dengan fungsi berbeda. Pada tahap ini aplikasi Unity 3D 2019 digunakan untuk membangun aplikasi dengan basis Android, beserta dengan 2 perangkat pendukung lainnya. Dengan bantuan smartphone peserta didik dapat belajar mandiri, menghemat waktu, dan aktif ketika pembelajaran (Rahardjo et al., 2019) Penyesuaian konten disusun sesuai konteks materi, perancangan desain dibuat dengan menarik sehingga didapatkan sebuah produk yang menarik dan sesuai kebutuhan berupa modul berbantuan Augmented Reality dengan puzzle. Dalam tahapan ini disusun pengembangan instrumen untuk menguji tingkat kelayakan produk yang disusun kepada reviewer media dan reviewer materi. Sedangkan pelaksanaan uji coba pemanfaatan produk dilaksanakan terhadap kelompok kecil yakni siswa SD kelas IV.

Menurut (Lee \& Owens, 2004), teknik analisis data yang dipergunakan dalam metode ini yakni Rating scale dengan penilaian yang didapatkan berdasarkan total data respon dari setiap poin pernyataan yang disajikan didalam angket. Berikut diantaranya merupakan acuan rating scale yang digunakan didalam aspek penilaian angket (1) sangat tidak setuju, (2) setuju, (3) tidak setuju, (4) sangat setuju.

Dalam penelitian, penggunaan rating scale digunakan dengan tujuan mengukur persepsi responden mengenai produk modul pengembangan ini. Sedangkan teknik pengumpulan data yang diterapkan dalam pengembangan ini menggunakan instrument berupa angket. Penggunaan 4 poin tingkatan penilaian angket diperlukan untuk menghilangkan keraguan, dan biasanya terdapat jumlah 5 tingkatan poin acuan yang mewakili arti ragu/netral. Maka dari itu hasil uji kelayakan dengan rating scale apabila data yang didapatkan dari angket mendapatkan poin mayoritas pada nilai (3) setuju, dan (4) sangat setuju, maka sebuah media mendapatkan respon positif dan dikatakan layak digunakan. Sedangkan apabila data mayoritas dalam angket yang telah dikumpulkan mendapatkan nilai (1) sangat tidak setuju, dan (2) tidak setuju, maka media yang dihasilkan dikatakan tidak layak.

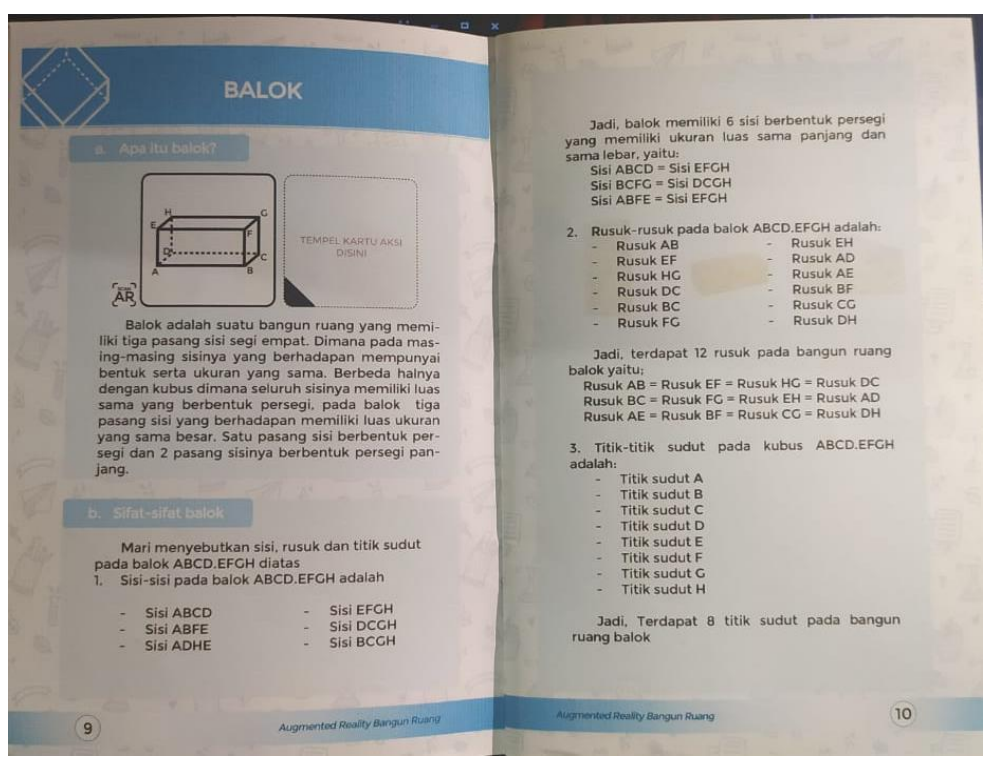

Gambar 2. Tampilan halaman modul dengan marker 


\section{HASIL}

Hasil pengembangan yang disusun adalah buku modul konten bangun ruang bergambar 2 dimensi. Pada modul berisikan materi, contoh dan soal latihan. Objek dua dimensi dimodifikasi menjadi marker yang memproyeksikan objek bentuk 3 dimensi ketika discan dengan aplikasi. Berikut pada gambar 3 ditunjukkan bagian pada modul yang terdapat gambar bangun ruang dan berfungsi sebagai marker.

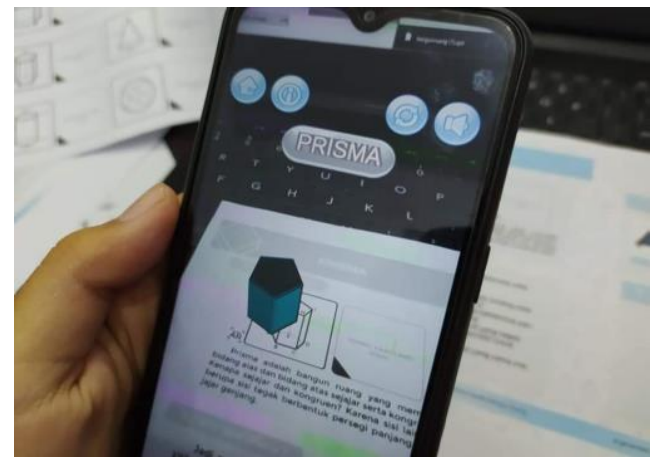

Gambar 3. Tampilan bangun ruang yang diproyeksikan

Apabila marker seperti gambar 3 diatas discan oleh aplikasi Augmented Reality, secara otomatis proyeksi objek 3 dimensi dimunculkan. Aplikasi Augmented Reality memproyeksikan objek 3D dari gambar 2D yang tercetak dalam buku adalah produk pengembangan. Setiap objek $3 \mathrm{D}$ yang muncul akan sesuai dengan jenis bangun ruang yang sedang discan. Berikut pada gambar 3 merupakan tampilan objek 3D ketika marker discan dengan aplikasi.

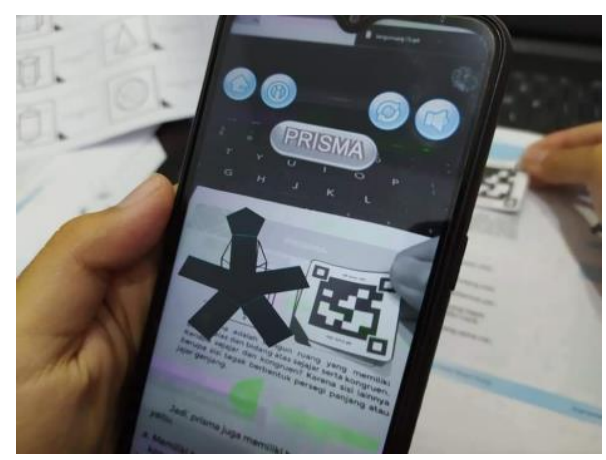

\section{Gambar 4. Tampilan bangun ruang disandingkan marker kartu aksi}

Animasi jaring bangun ruang dimunculkan apabila kartu aksi disandingkan dengan marker. Hal ini juga merupakan pengembangan berbeda dari pengembangan yang sudah ada. Sehingga siswa dapat lebih memahami karakteristik pada setiap bangun ruang dan menambah kemenarikan dalam produk yang dikembangkan. Ditunjukkan perbedaan pada gambar 4 ketika marker discan bersamaan dengan kartu aksi.

Hasil produk dari pengembangan tersebut dilakukan uji kelayakan pada ahli media dan ahli materi. adapun hasil tanggapan dari ahli media dan ahli materi pada modul berbantuan Augmented Reality dengan puzzle disajikan dalam grafik 1. 


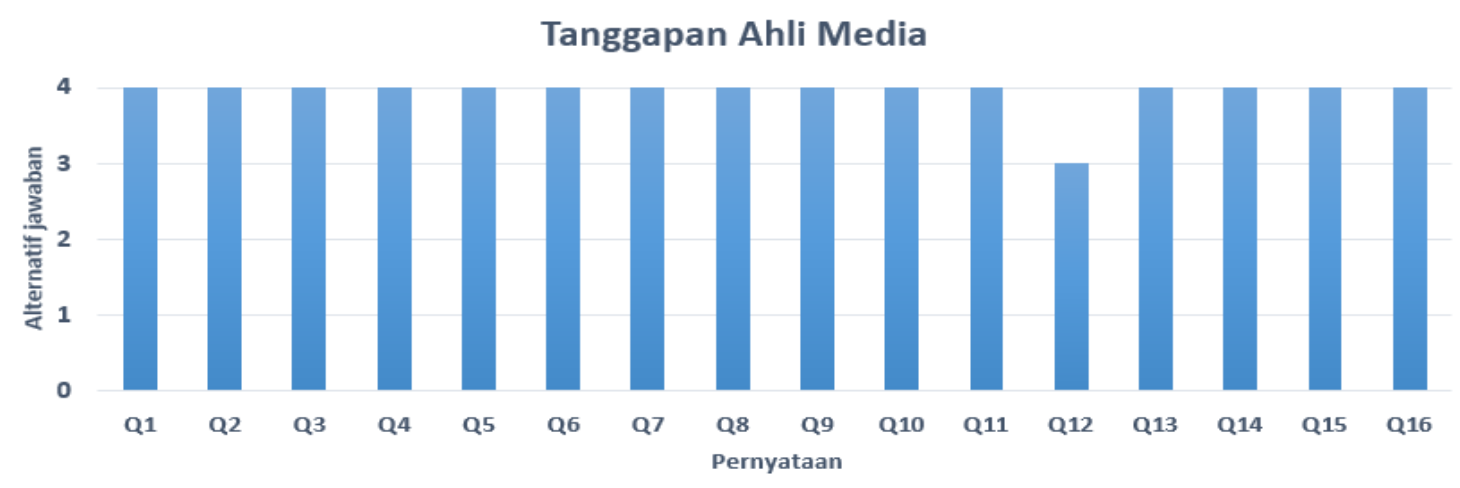

\section{Grafik 1. Diagram tanggapan Ahli Media}

Pada grafik 1 tanggapan ahli media dari 16 item pernyataan terdapat 15 item pernyataan memperoleh poin 4 dan 1 pernyataan memperoleh poin 3 pada Q12. Maka dari itu berdasar hasil tanggapan yang diperoleh, modul Augmented Reality dengan puzzle memperoleh respon positif dan layak digunakan. Selain itu adapun saran dan masukan dari Ahli media terhadap media modul Augmented Reality dengan puzzle ini berupa tambahan optimalisasi pada aspek petunjuk pemanfaatan. Untuk selebihnya ahli media memberikan respon tanggapan yang positif baik dari desain modul maupun user interface dari media modul Augmented Reality dengan puzzle

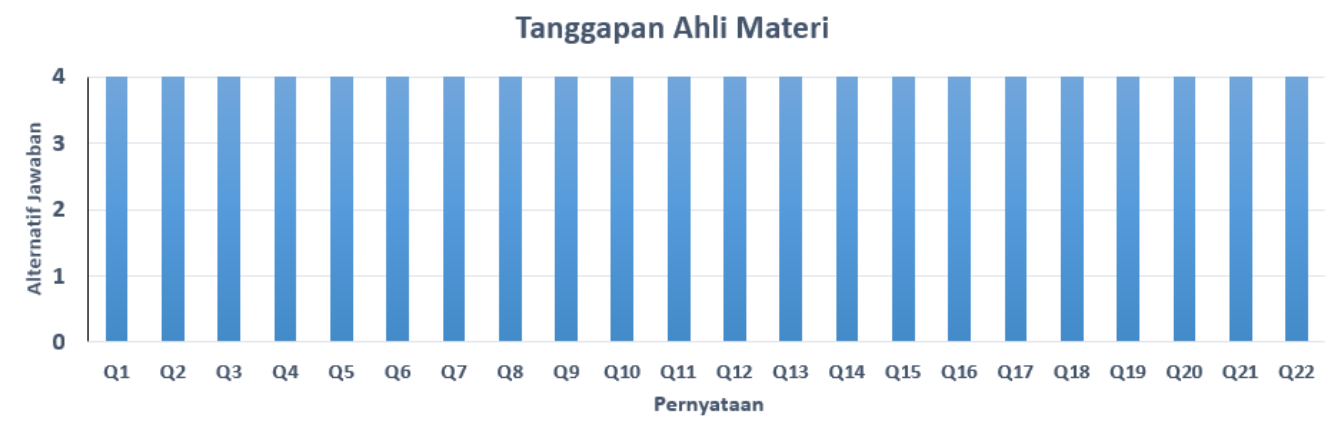

\section{Grafik 2. Diagram tanggapan Ahli Materi}

Berdasarkan grafik 2 diagram hasil tanggapan Ahli Materi dari 22 item pernyataan yang disajikan. Ditemukan bahwa 22 item pernyataan memperoleh poin 4. Berdasar hasil tanggapan yang diperoleh, modul Augmented Reality dengan puzzle memperoleh respon positif dan layak digunakan. Untuk selebihnya ahli media memberikan respon tanggapan yang positif terhadap produk baik dari kepadatan materi dan soal didalam modul maupun konten materi dalam aplikasi dari produk media modul Augmented Reality dengan puzzle.

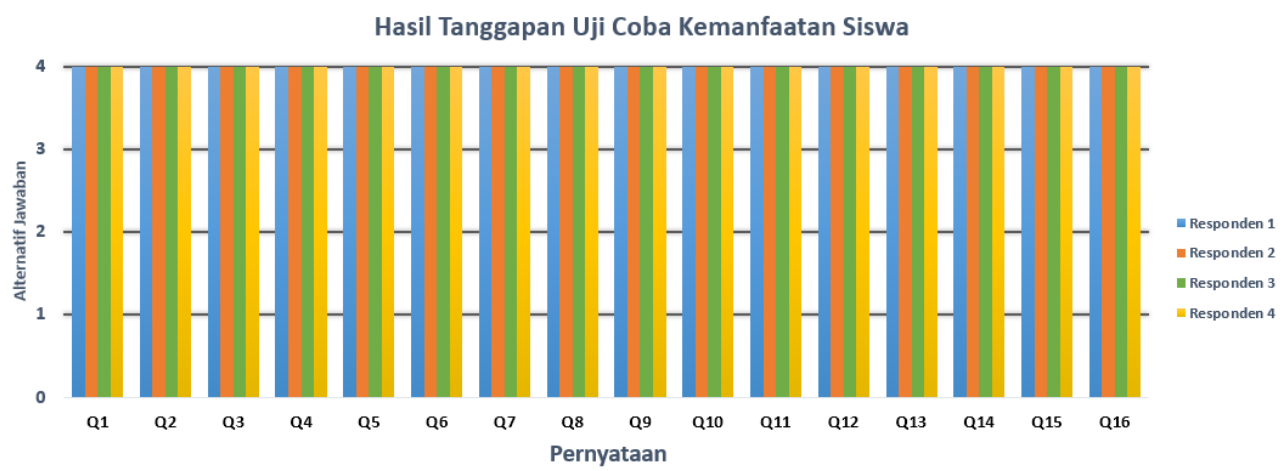

Grafik 3. Tanggapan Siswa 
Dari contoh grafik 3 hasil uji coba dalam aspek kemanfaatan produk dilakukan pada 4 Siswa. Tanggapan diperoleh dari responden satu 13 pernyataan memperoleh poin 4 . Tanggapan dari responden dua 13 pernyataan memperoleh poin 4. Tanggapan dari responden tiga 13 pernyataan memperoleh poin 4 . Tanggapan dari responden empat 13 pernyataan memperoleh poin 4. dari tanggapan yang diperoleh, modul Augmented Reality dengan puzzle mendapat respon positif dan layak digunakan.

\section{PEMBAHASAN}

Pada pengembangan produk modul berbantuan Augmented Reality dilakukan beberapa tahap yaitu, tahapan analisis. Tahapan ini dilakukan observasi untuk memahami kendala dan kebutuhan yang ada di lapangan agar pengembangan sesuai kebutuhan. Menurut Lee \& Owens (2004) pada tahap assessment terbagi menjadi 2 tahap yakni (1) analisis kebutuhan (need assesment) dan analisis awal-akhir (front-end analysis). Tahap analisis kebutuhan dilakukan observasi dan wawancara langsung kepada guru di sekolah yakni guru SD kelas IV. langkah selanjutnya menganalisis kebutuhan dengan mengumpulkan data karakteristik siswa, yaitu observasi dilakukan pada siswa SD kelas IV. menentukan materi, menentukan standar kompetensi yang dicapai dan memutuskan media yang digunakan dan mengidentifikasi kebutuhan belajar siswa.

Tahap (front-end analysis) berdasarkan dari hasil wawancara dan observasi. didapatkan kesimpulan adanya kesulitan siswa memahami konsep bentuk bangun ruang yang bersifat abstrak. Karena siswa memiliki potensi kecerdasan yang bermacam-macam. beberapa fakta bahwasannya kegiatan pembelajaran yang berpedoman pada buku cetak dan metode ceramah masih dirasa kurang optimal dalam memenuhi keberagaman karakteristik siswa. sehingga berakibat pada siswa tidak tercapai hasil belajar yang optimal. Oleh karena itu sebagai penunjang proses belajar pada siswa di kelas IV materi bangun ruang, teknologi Augmented Reality dipilih sebagai solusi penyelesaian kendala yang terjadi.

Tahap desain. Pada tahap ini mulai ditentukan model bentuk 3D yang akan ditampilkan dalam buku modul, desain buku modul menarik baik desain cover maupun desain susunan layout dan penyajian potongan kartu aksi terpisah dengan buku, desain User Interface pada aplikasi Augmented Reality, spesifikasi media, informasi konten dan kontrol konfigurasi.

Tahapan pengembangan, materi bangun ruang dikumpulkan dan disusun kedalam aplikasi dan modul. Pembuatan aplikasi Augmented Reality dibuat dari software utama yakni memanfaatkan aplikasi Unity 3D 2019 untuk menghasilkan aplikasi dengan basis Android, Vuforia sebagai database marker target manager dan Adobe Photoshop untuk mendesain UI dan Layout Modul. Tersedia 2 macam Marker dengan fungsi berbeda dipakai dalam media ini, pertama macam bangun ruang tercetak 2D di buku dan marker berbentuk kartu aksi berupa $Q R$-Code terpisah dari modul. Jika kartu aksi diletakkan berdampingan dengan marker 2D bangun ruang dapat memunculkan bentuk animasi jaring-jaring dari objek 3D yang sedang terproyeksi. Selanjutnya desain marker diunggah pada laman penyedia database marker target manager.

Pengembangan instrumen dilaksanakan untuk menguji bagaimana tingkat kelayakan produk modul Augmented Reality dengan puzzle kepada reviewer ahli media dan ahli materi. Serta uji coba penilaian pemanfaatan produk dilaksanakan terhadap kelompok kecil yakni dengan responden siswa SD kelas IV.

Augmented Reality yaitu salah satu teknologi penggabungan antara dunia nyata dengan dunia virtual, seolah tidak ada batas diantara keduanya. Sebagai media yang menjadi penengah diantara manusia dengan komputer dan komputer dengan manusia dan manusia dengan manusia, teknologi Augmented Reality dapat dikembangkan menjadi aplikasi menarik yang dimanfaatkan untuk berbagai tujuan dan tidak hanya ada sebagai sebuah pembaruan teknologi baru belaka. Teknologi 
AR juga dapat mendatangkan lingkungan yang baru dengan memanfatkan penambahan lingkungan virtual (Wang, 2009).

Modul berbantuan teknologi Augmented Reality dengan puzzle sebagai sumber belajar materi bangun ruang siswa kelas IV SD dikembangkan sebagai penunjang buku utama. Buku penunjang pembelajaran memiliki fungsi sebagai bahan untuk pengayaan bagi siswa (Kurniasari et al., 2014). Dapat disimpulkan buku penunjang atau buku pelengkap merupakan sebuah tambahan untuk buku utama bagi siswa. menurut (Jamhari et al., 2018) dalam pembelajaran perangkat-perangkat penunjang seperti sumber belajar diperlukan untuk membantu guru menyampaikan informasi atau pesan kepada siswa. Mengingat bahan sumber belajar konvensional berupa fisik atau cetak merupakan media paling mudah dioperasikan pendidik dalam penyampaian materi.

Penggunaan modul merupakan bentuk pembelajaran mengarah kepada bantuan, perhatian dan perlakuan khusus ditujukan kepada siswa dengan kepemilikan minat, kemampuan, pemahaman dan kecepatan berbeda-beda. Penelitian yang dilakukan oleh (Cusack \& O'Donoghue, 2012) menunjukkan bahwa siswa sangat setuju dan puas belajar menggunakan modul. Sehingga modul merupakan sumber belajar yang secara individual dapat membantu siswa untuk mencapai tujuan belajar.

Degeng dalam (Prasetiyo et al., 2018) Penggunaan media secara kombinasi adalah hal yang dimungkinkan. Hal ini searah dengan penelitian sebelumnya yang menyatakan bahwa kombinasi yang dimaksudkan berupa penggabungan antara media konvensional dengan teknologi. Hasil kombinasi berupa penggabungan antara benda nyata dengan benda virtual (Abdillah et al., 2020).

Kombinasi yang dimaksudkan disini berupa hasil penggabungan antara media dengan kecanggihan teknologi yang selalu berkembang, canggih dan modern. Seperti halnya benda tiruan yang disajikan kedalam bentuk virtual. Pemanfaatan teknologi AR dalam pembelajaran masih tahapan pertumbuhan sehingga sangat perlu untuk diamati seberapa besar potensinya untuk dimanfaatkan dalam menciptakan suasana belajar efektif (FitzGerald et al., 2013). Augmented Reality adalah sebuah perubahan unik dalam belajar dengan mobile device (Joan, 2015). Pemanfaatan Augmented Reality untuk pembelajaran terbukti mampu menarik minat siswa, memeberikan kenyamanan bagi siswa mempelajari materi melalui pemanfaatan AR (Wu et al., 2013). Maka dari itu karena perkembangan teknologi AR yang terus menerus dapat dimanfaatkan dalam berbagai bidang termasuk pendidikan, salah satunya pembelajaran matematika.

Modul yang dikembangkan adalah media dengan memanfaatkan teknologi Augmented Reality dengan penambahan fitur puzzle berbasis Android. Media memanfaatkan smartphone sangat praktis, dapat dilakukan dimanapun dan kapanpun (Puspitasari et al., 2020). Disajikan materi lengkap dalam modul mengenai contoh gambar, penjelasan, latihan soal serta contoh dalam kehidupan nyata. Aplikasi disertakan dalam smartphone android sehingga media dapat dipelajari secara mandiri dimana saja.

Dari hasil penelitian oleh (Soepriyanto et al., 2017). Sejalan dengan penelitian sebelumnya penggunaan Augmented Reality pebelajar dapat secara langsung berinteraksi dengan konten digital sehingga menunjang peningkatan abstraksi kreativitas, imajinasi dan belajar (Persefoni \& Tsinakos, 2015). Hasil penelitian penggunaan Augmented Reality dalam pembelajaran sains menunjukkan peningkatan kognitif yang lebih tinggi saat perancah digunakan (Yoon et al., 2012). Sesuai dengan pemaparan penelitian sebelumnya yang menghasilkan media pembelajaran mobile AR diklasifikasikan sangat efektif, efisien dan menyenangkan (Hidayat et al., 2018). Demikian pula dijelaskan pada penelitian sebelumnya berupa aplikasi Augmented Reality sebagai suplemen pada modul Bahasa isyarat mendapatkan penilaian valid sebagai media (Hapsari et al., 2019). 
Berdasarkan dengan tujuan pengembangan dan telah melalui serangkaian tahapan serta tanggapan didapatkan dari para ahli, modul berbantuan Augmented Reality dengan puzzle dikatakan bagus secara keseluruhan baik kelengkapan materi didalamnya. Hasil tanggapan ahli media dari 15 pernyataan mendapatkan poin 4 dan 1 pernyataan memperoleh nilai 3. Dari hasil ini menunjukkan modul berbantuan Augmented Reality dengan puzzle dikatakan layak digunakan. Dengan saran penambahan berupa tambahan optimalisasi pada aspek petunjuk pemanfaatan. Hasil tanggapan ahli materi dari 22 pernyataan mendapatkan poin 4 respon tanggapan positif terhadap produk baik kepadatan materi modul dan aplikasi dan soal didalam modul. Maka dari itu media modul Augmented Reality dengan puzzle dikatakan layak digunakan.

Sedangkan dalam hasil uji coba kemanfaatan produk modul Augmented Reality dengan puzzle diterapkan pada 4 siswa didapatkan dari responden satu 13 pernyataan memperoleh poin 4 . Tanggapan responden dua 13 pernyataan memperoleh poin 4. Tanggapan responden tiga 13 pernyataan memperoleh poin 4. Tanggapan responden empat 13 pernyataan memperoleh poin 4. Maka dari itu berdasarkan tanggapan yang diperoleh, modul Augmented Reality dengan puzzle memperoleh respon positif dan layak digunakan.

\section{SIMPULAN}

Penelitian pengembangan ini menghasilkan produk berbentuk modul berbantuan Augmented Reality dengan puzzle berisi materi bangun ruang serta aplikasi Augmented Reality berbasis Android. Produk ini adalah alternatif untuk melengkapi kekurangan pada pembelajaran matematika bangun ruang di SDN Punten 01 Batu. Hasil tanggapan dari ahli media diperoleh kriteria layak, hasil review ahli materi diperoleh kriteria layak dan hasil uji coba kelompok kecil diklarifikasi layak digunakan.

\section{DAFTAR RUJUKAN}

Abdillah, A. F., Degeng, I. N. S., \& Husna, A. (2020). Pengembangan Buku Suplemen dengan Teknologi 3D Augmented Reality sebagai Bahan Belajar Tematik untuk Siswa Kelas 4 SD. JINOTEP (Jurnal Inovasi Dan Teknologi Pembelajaran): Kajian Dan Riset Dalam Teknologi Pembelajaran, 6(2), 111-118.

Billinghurst, M. (2002). Augmented reality in education. New Horizons for Learning, 12(5), 1-5.

Cusack, T., \& O'Donoghue, G. (2012). The introduction of an interprofessional education module: students' perceptions. Quality in Primary Care, 20(3), 231-238.

FitzGerald, E., Ferguson, R., Adams, A., Gaved, M., Mor, Y., \& Thomas, R. (2013). Augmented reality and mobile learning: the state of the art. International Journal of Mobile and Blended Learning (IJMBL), 5(4), 43-58.

Hapsari, N. D., Toenlioe, A. J. E., \& Soepriyanto, Y. (2019). Pengembangan Augmented Reality Video Sebagai Suplemen Pada Modul Bahasa Isyarat. Jurnal Kajian Teknologi Pendidikan, l(3), 185-194.

Hidayat, D. W., Kuswandi, D., \& Ulfa, S. (2018). Pembelajaran organisasi makhluk hidup berbasis gamification menggunakan mobile augmented reality. JINOTEP (Jurnal Inovasi Dan Teknologi Pembelajaran): Kajian Dan Riset Dalam Teknologi Pembelajaran, 4(1), 914.

Jamhari, I., Susilaningsih, S., \& Ulfa, S. (2018). Pengembangan Buku Suplemen 3d Augmented Reality Sebagai Bahan Belajar Tematik Tema Lingkungan Tentang Perkembangbiakan Hewan Untuk Siswa Kelas III SD. JINOTEP (Jurnal Inovasi Dan Teknologi Pembelajaran): Kajian Dan Riset Dalam Teknologi Pembelajaran, 4(2), 76-81.

Joan, D. R. (2015). Enhancing education through mobile augmented reality. Journal of Educational Technology, 11(4), 8-14. 
Kurniasari, D. A. D., Rusilowati, A., \& Subekti, N. (2014). Pengembangan buku suplemen IPA terpadu dengan tema pendengaran kelas VIII. Unnes Science Education Journal, 3(2).

Lee, W. W., \& Owens, D. L. (2004). Multimedia-based instructional design: computer-based training, web-based training, distance broadcast training, performance-based solutions. John Wiley \& Sons.

Meyer, R. (1978). Designing learning modules for inservise teacher education. Australia: Centre for Advancement of Teaching.

Nincarean, D., Alia, M. B., Halim, N. D. A., \& Rahman, M. H. A. (2013). Mobile augmented reality: The potential for education. Procedia-Social and Behavioral Sciences, 103, 657664.

No, P. (22 C.E.). Tahun 2016. Tentang Standar Proses Pendidikan Dasar Dan Menengah.

Orlich, D. C., Harder, R. J., Callahan, R. C., Trevisan, M. S., \& Brown, A. H. (2012). Teaching strategies: A guide to effective instruction. Cengage Learning.

Persefoni, K., \& Tsinakos, A. (2015). Use of Augmented Reality in terms of creativity in School learning. Workshop of Making as a Pathway to Foster Joyful Engagement and Creativity in Learning (Make2Learn), 45.

Piaget, J. (1976). Piaget's theory. In Piaget and his school (pp. 11-23). Springer.

Prasetiyo, T. K., Setyosari, P., \& Sihkabuden, S. (2018). Pengembangan Media Augmented Reality Untuk Program Keahlian Teknik Gambar Bangunan Di Sekolah Menengah Kejuruan. JINOTEP (Jurnal Inovasi Dan Teknologi Pembelajaran): Kajian Dan Riset Dalam Teknologi Pembelajaran, 4(1), 37-46.

Puspitasari, D., Praherdiono, H., \& Adi, E. P. (2020). Pengembangan Suplemen Augmented Reality Animation Pada Buku Mata Pelajaran Biologi Untuk Penguatan Kognitif Siswa SMA. Jurnal Kajian Teknologi Pendidikan, 3(1), 29-39.

Rahardjo, T., Degeng, N., \& Soepriyanto, Y. (2019). Pengembangan Multimedia Interaktif Mobile Learning Berbasis Anrdroid Aksara Jawa Kelas X Smk Negeri 5 Malang. Jurnal Kajian Teknologi Pendidikan, 2(3), 195-202. https://doi.org/10.17977/um038v2i32019p195

Rusnandi, E., Sujadi, H., \& Fauzyah, E. F. N. (2016). Implementasi augmented reality (ar) pada pengembangan media pembelajaran pemodelan bangun ruang 3D untuk siswa Sekolah Dasar. INFOTECH Journal, 1(2).

Soepriyanto, Y., Sulthoni, S., \& Ulfa, S. (2017). Pengembangan Augmented Reality Sebagai Electronic Performance Support System Dalam Pembelajaran. Edcomtech Jurnal Kajian Teknologi Pendidikan, 2(1), 1-10.

Wang, X. (2009). Augmented reality in architecture and design: potentials and challenges for application. International Journal of Architectural Computing, 7(2), 309-326.

Wu, H.-K., Lee, S. W.-Y., Chang, H.-Y., \& Liang, J.-C. (2013). Current status, opportunities and challenges of augmented reality in education. Computers \& Education, 62, 41-49.

Yoon, S. A., Elinich, K., Wang, J., Steinmeier, C., \& Tucker, S. (2012). Using augmented reality and knowledge-building scaffolds to improve learning in a science museum. International Journal of Computer-Supported Collaborative Learning, 7(4), 519-541. 